\title{
STRATEGI PIMPINAN FAKULTAS ILMU SOSIAL DAN ILMU POLITIK UNIVERSITAS TADULAKO DALAM MENGKOMUNIKASIKAN KEBIJAKAN KEPADA MAHASISWA
}

\author{
Donal Adrian \\ donal.adrian2014@gmail.com \\ Universitas Tadulako, Palu
}

\begin{abstract}
The purposes of this research are (1) to provide the image and analyze strategy leaders the faculty of social and political science, Tadulako University in communicate policy to students and (2) to provide the image and analyze factors barrier in the communications strategy done by the leader of politics, Tadulako University. The results of the study showed that the imparting of implementing the policy of, used three the components the communications strategy namely communicators seen from office and attractiveness to such as have friendly attitude, discipline and forcefully so as to cause more students ask any questions directly to them. The message delivered by the leader of packed with so well that can catch a student. The process of design twang of them use the area of a Palu City and a message that based on the experiences of a leaders when lecture carry out whose aim to motivate students. Components the third is media. It was used the non-personal media, example are banners and a guidebook academic the faculty. As for factors barrier in its implementation that is some students still showing conduct that is as good as meniruh signature a classmate in absent lecture and do remedial lecture than the command of by the number of a maximum of three courses.
\end{abstract}

\section{Key Words : Communication Strategy, Organization, Policy}

\begin{abstract}
Abstrak
Penelitian ini bertujuan (1) untuk memberikan gambaran dan menganalisis strategi pimpinan Fakultas Ilmu Sosial dan Ilmu Politik, Universitas Tadulako dalam mengkomunikasikan kebijakan kepada mahasiswa dan (2) untuk memberikan gambaran dan menganalisis faktor-faktor penghambat dalam strategi komunikasi yang dilakukan oleh pimpinan Fisip, Untad. Hasil penelitian menunjukan bahwa dalam menyampaikan penerapan kebijakan, digunakan tiga (3) komponen strategi komunikasi yaitu komunikator yang dilihat dari jabatan dan daya tarik seperti memiliki sikap yang ramah, disiplin dan tegas sehingga menyebabkan mahasiswa lebih banyak bertanya secara langsung kepada mereka. Pesan yang disampaikan oleh pimpinan dikemas dengan sangat baik sehingga dapat menarik perhatian mahasiswa. Proses pengemasannya diantaranya menggunakan logat daerah kota Palu dan pesan yang didasarkan pada pengalaman seorang pimpinan ketika melaksanakan perkuliahan yang tujuannya untuk memotivasi mahasiswa. Komponen yang ketiga adalah media. Media yang digunakan yaitu media non-personal berupa media spanduk dan buku panduan akademik fakultas. Adapun faktor-faktor penghambat dalam pelaksanaannya yaitu sebagian mahasiswa masih menunjukkan perilaku yang tidak baik seperti meniruh tanda tangan teman sekelas pada absen perkuliahan dan melakukan remedial mata kuliah melebihi dari ketetapan dengan jumlah maksimal tiga (3) mata kuliah.
\end{abstract}

Kata Kunci : Strategi Komunikasi, Organisasi, Kebijakan 


\section{Pendahuluan}

Komunikasi yang efektif dianggap sangat penting, tidak hanya untuk manusia itu sendiri tapi juga untuk sebuah organisasi. Komunikasi menjadi bagian terpenting dan bahkan sering dibahas. Dalam kenyataannya masalah komunikasi selalu muncul dalam proses organisasi, oleh sebab itu komunikasi dalam organisasi menjadi sistem aliran yang menghubungkan dan membangkitkan kinerja antar bagian dalam organisasi sehingga dapat menghasilkan sinergi. Untuk itu, berdasarkan manfaat yang telah didapatkan oleh sebuah organisasi maka komunikasi secara umum harus juga dipandang sebagai struktur organisasi.

Struktur organisasi dibentuk sebagai cara untuk mencapai tujuan organisasi yang harus sejalan dengan strategi organisasi. Strategi organisasi merupakan bentuk pelaksanaan untuk mengatur organisasi dengan memperhatikan berbagai macam komponen yang saling mempengaruhi satu sama lainnya atau tersistem. Hal ini merupakan ciri umum organisasi.

Dalam suatu organisasi perlu dibuat aturan-aturan yang disertai dengan sanksi tegas bagi anggota organisasi yang melanggarnya. Fungsi dari aturan (kebijakan) pada dasarnya dijadikan sebagai pedoman dalam melaksanakan aktivitas organisasi sehingga dapat mencapai tujuan yang diinginkan. Namun, untuk memberikan pemahaman yang baik mengenai aturan yang ada, maka dibutuhkan juga peran pimpinan sebagai pusat informasi (komunikator) yang tentunya memiliki keterampilan atau kemampuan dalam berkomunikasi dengan baik.

Kemampuan berkomunikasi tersebut di atas bisa dilihat dari bagaimana seorang komunikator harus pandai dalam mengemas pesan yang akan disampaikan, pesan yang dikemas harus mampu membangkitkan perhatian sasaran komunikasi, memilih media yang tepat dan tentu saja harus disesuaikan dengan kebutuhan sasaran (needs). "Suatu pesan hanya akan menarik perhatian selama ia memberikan harapan atau hasil yang ada dan kuat relevansinya dengan persoalan needs" (Ahmad 1994 dalam Nurhaidar 2009:8). Dengan adanya fungsi pesan yang merupakan unsur komunikasi, pada dasarnya bertujuan untuk merubah sikap, tingkah laku dan pola pikir sasarannya demi mencapai apa yang diinginkan dalam lingkup organisasi.

Penyusunan pesan yang baik tidak mutlak menjadikan komunikasi itu efektif. Penggunaan media yang tepat dalam menyampaikan pesan kepada khalayak juga menjadi pertimbangan utama dalam menunjang keberhasilan komunikasi. Media yang dipilih dalam menyampaikan pesan seperti pesan tentang penegakkan kebijakan pada suatu fakultas harus disesuaikan dengan karakteristik civitas akademika baik dari kondisi dan keadaannya yang mudah untuk dilihat atau disaksikan. Komunikasi yang efektif dapat terjadi di organisasi mana pun, seperti halnya organisasi formal.

Universitas Tadulako merupakan sarana pendidikan dengan status negeri yang unggul dalam berprestasi serta banyak diminati oleh para calon intelektual muda baik di dalam ataupun di luar provinsi Sulawesi Tengah. Pada perkembangannya, universitas yang berada di kota Palu ini, telah memiliki sembilan fakultas, salah satunya adalah Fakultas Ilmu Sosial dan Ilmu Politik sebagai lembaga pendidikan yang bertujuan untuk menghasilkan produktivitas sumber daya manusia yang baik yaitu menghasilkan mahasiswa yang dapat bersaing di era modern sekarang ini. 
Persaingan yang sangat ketat tentunya menuntut para pimpinan agar dapat menjalankan fungsinya dengan baik dan maksimal, seperti menyusun kebijakan atau peraturan yang ditujukan untuk semua mahasiswa dengan tujuan untuk membantu proses perkuliahan menjadi terarah dan sistematis. Namun, berdasarkan fenomena yang terjadi di Fakultas Ilmu Sosial dan Ilmu Politik, kebijakan yang telah ditetapkan oleh pimpinan sering kali dilanggar dengan berbagai macam alasan yang berbedabeda baik secara individu ataupun kelompok dari mahasiswa itu sendiri. Masalah tersebut dapat dibuktikan dengan penuturan dari seorang mahasiswa Fisip yang bernama Dwi Setia Y, dia menyatakan bahwa :

Pada awal masuk kuliah tahun 2007 sampai 2009, saya pernah mengikuti ujian final tapi dengan presentasi kehadiran $53 \%$ namun mendapatkan nilai $B$, selain itu biasanya saya juga meminta tolong kepada teman sekelasku untuk ditanda tangankan di daftar kehadiran mahasiswa (absen kelas) jika pada hari itu saya berhalangan hadir atau lambat masuk kelas pada saat jam mata kuliah berlangsung.

Selain berkaitan dengan presentasi kehadiran, kebijakan yang lain adalah aturan mengenai remedial mata kuliah yang dilaksanakan oleh setiap mahasiswa yang nantinya akan menempuh ujian skripsi. Remedial mata kuliah itu dilakukan mahasiswa hanya dengan memberikan blangko perbaikan nilai mata kuliah kepada dosen yang bersangkutan dengan membayar per sks senilai Rp 35.000,- tanpa mengerjakan tugas sebagai syarat lulus mata kuliah. Pernyataan ini senada dengan ungkapan dari Vahmiyati mahasiswa FISIP angkatan 2006, menyatakan bahwa :

Sebelum mengikuti ujian akhir skripsi tahun 2011, terlebih dahulu saya mengikuti remedial mata kuliah dengan dosen. Mata kuliah itu berjumlah dua dengan per sks nya Rp. 35.000,-. Remedial mata kuliah itu ditujukan kepada dua orang dosen sebagai penanggungjawab, pada saat itu dosen yang satu langsung memberikan nilai sedangkan dosen yang satunya lagi sebelum memberikan nilai, dosen tersebut memberikan tugas-tugas berupa makalah sebagai syarat untuk lulus mata kuliah yang diremedialkan.

Berdasarkan masalah yang ada maka kebijakan yang telah ditetapkan harus lebih ditegakkan atau didisplinkan lagi seperti memberikan sanksi yang tegas untuk tidak mengikutsertakan mahasiswa pada saat ujian semester atau melaksanakan proses belajar formal di fakultas. Harapannya yaitu agar mahasiswa bisa sadar dan mengerti bahwa untuk menjadi seorang sarjana dengan hasil yang memuaskan dan dapat diterima dengan baik di lingkungan pekerjaan yang baru, tentunya dibutuhkan suatu keseriusan atau kesungguhan dari dalam diri sendiri. Namun, untuk menegakkan kebijakan para pimpinan harus menentukan strategi yang baik sehingga dapat membantu mereka untuk mengetahui karakteristik dari sasarannya (mahasiswa) itu sendiri. Penentuan strategi ini dapat dilihat dengan cara menggunakan sebagian unsur-unsur komunikasi.

Terkait dengan adanya
fenomena yang telah dipaparkan
tersebut, maka peneliti menganggap
bahwa hal itu sangat baik untuk dikaji,
karena dapat bermanfaat untuk semua
orang khususnya bagi para individu
yang memegang jabatan tertinggi di
lingkungan fakultas. Sehingga bisa


menerapkannya dalam kehidupan sehari-hari kepada civitas akademika secara keseluruhan.

\section{Rumusan Masalah}

Berdasarkan latar belakang masalah di atas, maka yang menjadi permasalahannya adalah sebagai berikut:

1. Bagaimana strategi pimpinan Fakultas Ilmu Sosial dan Ilmu Politik Universitas Tadulako dalam mengkomunikasikan kebijakan kepada mahasiswa?

2. Apa faktor-faktor penghambat dalam pelaksanaan strategi tersebut?

\section{Tujuan Penelitian}

Sejalan dengan rumusan masalah di atas, maka tujuan yang ingin dicapai dalam penelitian ini adalah :

1. Untuk memberikan gambaran dan menganalisis strategi pimpinan Fakultas Ilmu Sosial dan Ilmu Politik, Universitas Tadulako dalam mengkomunikasikan kebijakan kepada mahasiswa.

2. Untuk memberikan gambaran dan menganalisis faktor-faktor penghambat dalam strategi komunikasi yang dilakukan oleh pimpinan Fisip, Universitas Tadulako

\section{Tinjauan Pustaka}

\section{Komunikasi Organisasi}

Secara sederhana, komunikasi organisasi diartikan sebagai komunikasi antar manusia (human communication) yang terjadi dalam konteks organisasi. Thayer (Muhammad, 2007:66) menggunakan pendekatan sistem secara umum dalam memandang komunikasi organisasi. Menurutnya, tiga sistem komunikasi dalam organisasi, yaitu: a. Berkenaan dengan kerja organisasi seperti data mengenai tugas-tugas atau beroperasinya organisasi;

b. Berkenaan dengan pengaturan organisasi seperti perintahperintah, aturan-aturan dan petunjuk-petunjuk;

c. Berkenaan dengan pemeliharaan dan pengembangan organisasi.

Pace dan Faules (Lampe, 2011:7) Komunikasi organisasi terjadi kapanpun setidak-tidaknya satu orang yang menduduki suatu jabatan dalam suatu organisasi, analisis komunikasi organisasi menyangkut pertunjukan dan penafsiran pesan diantara lusinan atau bahkan ratusan individu pada saat yang sama yang memiliki jenis-jenis hubungan yang berlainan yang menghubungkan mereka, yang pikiran, keputusan dan perilakunya diatur oleh kebijakan-kebijakan, regulasi dan aturan-aturan yang mempunyai gaya berlainan dalam berkomunikasi, mengelola dan memimpin yang dimotivasi oleh kemungkinankemungkinan berbeda; yang berada pada tahap berlainan dalam berbagai kelompok; yang mempersepsi iklim komunikasi berbeda; yang mempunyai tingkat kepuasan berbeda; yang mempunyai tingkat ketelitian pesan yang berlainan; dan yang membutuhkan penggunaan tingkat materi dan energi yang berbeda untuk berkomunikasi efektif.

\section{Kebijakan}

Menurut Carl Friedrich (dalam Purnamasari, 2011: 9) mengatakan bahwa kebijakan:

Kebijakan ialah suatu tindakan yang mengarah pada tujuan yang diusulkan oleh seseorang, kelompok atau pemerintah dalam lingkungan tertentu sehubungan dengan 
adanya hambatan tertentu seraya mencari peluang-peluang untuk mencapai tujuan untuk mewujudkan sasaran yang diinginkan.

Bayu Suryaningrat (dalam Purnamasari, 2011: 9) mengatakan bahwa hal kebijakan dapat dilihat dari tiga (3) bagian :

1. Hak bijaksana, kepandaian menggunakan akal budi (pengalaman dan pengetahuan

2. Pimpinan dan cara bertindak (mengenai pemerintahan, perkumpulan dan sebagainya)

3. Kecakapan bertindak bila menghadapi orang lain (kesulitan dan sebagainya).

Kebijakan menurut George A. Steiner (Nurhayani, 2011: 9). Kata kerja kebijakan :

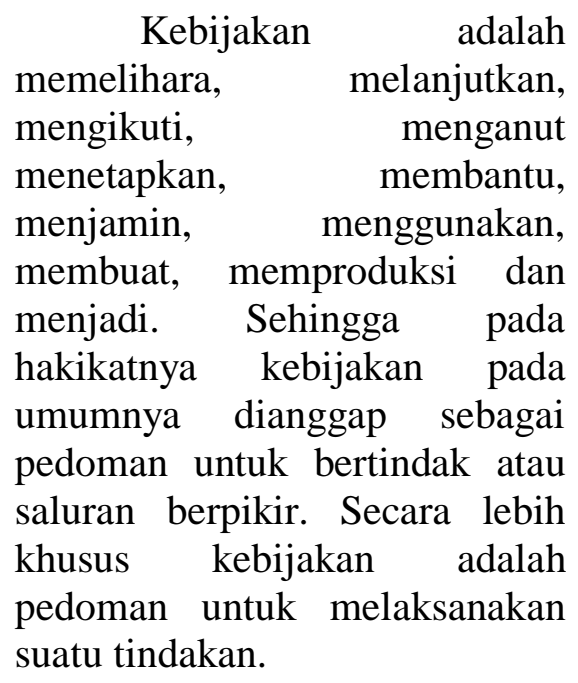

\section{Konsep Strategi Komunikasi dan Kaitannya dengan teori AIDDA}

Menurut Effendy (2003:301) strategi komunikasi merupakan paduan dari perencanaan komunikasi (communication planning) dan manajemen komunikasi (communication manajement) untuk mencapai suatu tujuan (goal). Untuk mencapai tujuan tersebut strategi komunikasi harus dapat menunjukkan bagaimana operasionalnya secara taktis harus dilakukan dalam arti kata bahwa pendekatan (approach) bisa berbedabeda sewaktu-waktu, bergantung pada situasi dan kondisi.

Menurut Arifin (1994: 59) strategi komunikasi merupakan keseluruhan keputusan kondisional tentang tindakan yang akan dijalankan guna mencapai tujuan. Dapat dikatakan bahwa dalam merumuskan strategi komunikasi, selain diperlukan rumusan tujuan yang jelas, juga perlu mengetahui kondisi dan situasi khalayak yang menjadi sasaran.

Dalam rangka menyusun strategi komunikasi diperlukan suatu pemikiran dengan memperhitungkan faktor-faktor pendukung dan faktor-faktor penghambat pada setiap komponen tersebut. Adapun komponen strategi komunikasi yang dimaksud adalah; Komunikan sebagai sasaran komunikasi, media, pesan, dan komunikator (Effendy, 2005: 35). Untuk lebih jelasnya dapat dilihat pada pemaparan berikut :

\section{Komunikator}

Cangara (2010:85) komunikator adalah pihak yang mengirimkan pesan kepada khalayak. Oleh karena itu, komunikator biasa disebut pengirim, sumber, source atau encoder. Sebagai pelaku utama dalam proses komunikasi, komunikator memegang peranan penting, terutama dalam mengendalikan jalannya komunikasi. Untuk itu, seorang komunikator harus terampil berkomunikasi, dan juga kaya ide serta penuh daya kreativitas. Para ahli komunikasi cenderung untuk samasama berpendapat bahwa dalam melancarkan komunikasi lebih baik menggunakan pendekatan yang disebut A-A Procedure (from Attention to Action Procedure) dengan lima langkah yang disingkat AIDDA, (Effendy, 2003:304). 


$\begin{array}{ll}\text { A } & \text { : Attention (perhatian) } \\ \text { I } & \text { : Interest (minat) } \\ \text { D } & \text { : Desire (hasrat) } \\ \text { D } & \text { : Decision (keputusan) } \\ \text { A } & \text { : Action (kegiatan) }\end{array}$

Komunikasi dimulai dengan membangkitkan perhatian komunikan. Apabila perhatian komunikan telah terbangkitkan, hendaknya disusul dengan upaya menumbuhkan minat (interest), yang merupakan derajat yang lebih tinggi dari perhatian yang merupakan titik tolak bagi timbulnya hasrat (desire) untuk melakukan suatu kegiatan yang diharapkan komunikator. Hanya ada hasrat saja pada diri komunikan, bagi komunikator belum berarti apa-apa, sebab harus dilanjutkan dengan datangnya keputusan (decision), yakni keputusan untuk melakukan kegiatan (action) sebagaimana diharapkan komunikator.

Selain itu juga, menurut Effendy (2003:43-44) juga mengatakan bahwa ada dua faktor penting pada diri komunikator yang dapat membantu dalam melancarkan komunikasi yaitu kepercayaan kepada komunikator (source credibility) dan daya tarik kepada komunikator (source attractiveness).

\section{Pesan}

Secara singkatnya, pesan adalah gagasan, perasaan, atau pemikiran yang telah di-encode oleh pengirim atau didecode oleh penerima, (Orbe \& Brues, 2005) dalam (Liliweri, 2011:40). Pada umumnya, pesan-pesan berbentuk sinyal, simbol, tanda-tanda atau kombinasi dari semuanya dan berfungsi sebagai stimulus yang akan direspons oleh penerima, (DeVito, 1986) dalam (Liliweri, 2011:40).

(Liliweri, 2011:40), menyatakan bahwa pesan-pesan mempunyai karakteristik, diantaranya yaitu :
1. Origin, pesan asli karena pesan ini merupakan simbol atau tanda yang berasal dari lingkungan fisik disekitarnya. Hal ini untuk membedakan antara pesan yang diciptakan melalui komunikasi interpersonal dan antarpersonal.

2. Mode, pesan yang tampil dalam bentuk visualisasi sehingga memungkinkan indra manusia memberikan makna terhadap pesan ini.

3. Physical Character, pesan yang memiliki ukuran, warna, kecerahan, dan intensitas.

4. Organization, merupakan pesan yang mengandung idea atau pendapat. Supaya pesan ini mudah dimengerti, maka pengirim menyusun (mengorganisasikan) pesan ini berdasarkan criteria tertentu.

5. Novelty, atau kebaruan, kemutakhiran adalah pesan yang mudah diterima karena ditampilkan secara khas atau pesan yang tampil beda, sehingga mudah menggugah indra manusia.

\section{Media}

Cangara (2010:123) Media adalah alat atau sarana yang digunakan sumber untuk menyampaikan pesan komunikator kepada khalayak. Media yang dimaksud dalam hal ini adalah media publik. Media publik adalah alat yang digunakan untuk menyampaikan pesan kepada khalayak yang lebih dari 200 -an orang. Untuk dapat mencapai sasaran komunikasi, peran media sebagai wahana penyampai pesan harus menjadi pertimbangan penting bagi seorang perumus strategi. Pemilihan media hendaknya bergantung pada 
tujuan yang akan dicapai, pesan yang akan disampaikan dan tehnik yang akan dipergunakan (Effendy, 2005:37).

\section{Komunikan}

Effendy (2005: 35), mengatakan bahwa ada dua faktor yang perlu diperhatikan dari diri komunikan, yaitu : pertama, faktor kerangka referensi (frame of reference), faktor ini terbentuk dalam diri seorang komunikan sebagai hasil dari paduan pengalaman, pendidikan, gaya hidup, norma hidup, status sosial, ideologi, cita-cita dan sebagainya. Kerangka referensi seseorang tentunya tidak sama dengan orang lain. Kedua, faktor situasi dan kondisi. Faktor situasi yang dimaksud adalah situasi pada saat komunikan akan menerima pesan yang disampaikan oleh seorang komunikator, sedangkan faktor kondisi merupakan state of personality komunikan, yaitu keadaan fisik dan psikis komunikan pada saat ia menerima pesan komunikasi.

\section{Metode Penelitian}

Jenis penelitian yang digunakan adalah kualitatif yang bertujuan untuk memberikan gambaran secara sistematis, aktual dan akurat dalam mendapatkan data yang kemudian dijabarkan melalui kalimat berbentuk huruf. Pendekatan yang digunakan adalah studi kasus. Karena di dalam penelitian ini terdapat masalah-masalah seperti adanya pelanggaran aturan yang dilakukan oleh mahasiswa dan dosen terkait dengan presentasi kehadiran di dalam kelas minimal $75 \%$. Teknik pengambilan sampelnya purposive sampling dengan menggunakan informan kunci. Teknik pengumpulan data yaitu observasi dan wawancara mendalam. Dan untuk teknik analisis data menggunakan reduksi data.

\section{Pembahasan}

Para ahli komunikasi cenderung untuk sama-sama berpendapat bahwa dalam melancarkan komunikasi lebih baik menggunakan pendekatan yang disebut A-A Procedure (from Attention to Action Procedure) dengan lima langkah yang disingkat AIDDA, (Effendy, 2003:304).
A : Attention (perhatian)
I : Interest (minat)
D : Desire (hasrat)
D : Decision (keputusan)
A : Action (kegiatan)

Komunikasi dimulai dengan membangkitkan perhatian komunikan. Apabila perhatian komunikan telah terbangkitkan, hendaknya disusul dengan upaya menumbuhkan minat (interest), yang merupakan derajat yang lebih tinggi dari perhatian yang merupakan titik tolak bagi timbulnya hasrat (desire) untuk melakukan suatu kegiatan yang diharapkan komunikator. Hanya ada hasrat saja pada diri komunikan, bagi komunikator belum berarti apa-apa, sebab harus dilanjutkan dengan datangnya keputusan (decision), yakni keputusan untuk melakukan kegiatan (action) sebagaimana diharapkan komunikator.

Menurut Cangara (2010:85) komunikator adalah pihak yang mengirimkan pesan kepada khalayak. Oleh karena itu, komunikator biasa disebut pengirim, sumber, source atau encoder. Sebagai pelaku utama dalam proses komunikasi, komunikator memegang peranan penting, terutama dalam mengendalikan jalannya komunikasi. Dalam penelitian ini, komunikator yaitu para pimpinanpimpinan fakultas yang dimulai dair pimpinan tertinggi yaitu Dekan FISIP Universitas Tadulako, Pembantu Dekan 1, Pembantu Dekan 3 dan bersama ketua jurusan. Berdasarkan hasil 
penelitiannya bahwa mereka menyampaikan informasi tentang kebijakan yang baru dibuat oleh dekan untuk bisa diterapkan dengan baik dalam proses belajar mengajar di kampus yaitu pada Fakultas Ilmu Sosial dan Ilmu Politik, Universitas Tadulako.

Pesan adalah gagasan, perasaan, atau pemikiran yang telah di-encode oleh pengirim atau di-decode oleh penerima, (Orbe \& Brues, 2005) dalam (Liliweri, 2011:40). Pada umumnya, pesan-pesan berbentuk sinyal, simbol, tanda-tanda atau kombinasi dari semuanya dan berfungsi sebagai stimulus yang akan direspons oleh penerima, (DeVito, 1986) dalam (Liliweri, 2011:40). Dari hasil penelitian yang ada bahwa pesan yang digunakan bisa berbentuk verbal dan non verbal. Dalam proses belajar mengajar, secara verbal bahwa pesan yang digunakan terkait kebijakan yang dibuat oleh dekan Fisip disampaikan secara langsung atau tatap muka oleh dosen-dosen Fisip baik dengan menggunakan bahasa Indonesia dan juga bahasa yang sering digunakan dalam komunikasi sehari-hari yaitu dengan menggunakan aksen orang Palu atau bahkan menggunakan bahasa daerah Palu.

Menurut Cangara (2010:123), media adalah alat atau sarana yang digunakan sumber untuk menyampaikan pesan komunikator kepada khalayak. Media yang dimaksud dalam hal ini adalah media publik. Media publik adalah alat yang digunakan untuk menyampaikan pesan kepada khalayak yang lebih dari 200-an orang. Untuk dapat mencapai sasaran komunikasi, peran media sebagai wahana penyampai pesan harus menjadi pertimbangan penting bagi seorang perumus strategi. Pemilihan media hendaknya bergantung pada tujuan yang akan dicapai, pesan yang akan disampaikan dan tehnik yang akan dipergunakan (Effendy, 2005:37). Dalam hasil penelitiannya bahwa ditemukan bahwa media yang digunakan sata menyampaikan kebijakan tersebut yaitu dengan menggunakan media tradisional yaitu bahasa, dan menggunakan media spanduk serta buku panduan. Dalam penggunaan buku panduan, setiap mahasiswa dibagikan buku tersebut untuk bsai dibaca dengan baik kemudian diimplementasikan melalui tindakan positif yaitu dengan cara mengikuti aturan yang telah ditetapkan.

Berdasarkan tiga indikator tersebut yaitu komunikator, pesan dan media yang kemudian dikaitkan dengan teori AIDDA bahwa dari segi perhatian yaitu dekan Fisip membuat kebijakan berupa kehadiran $75 \%$ dan nilai dalam remedial mata kuliah yang kemudian dipajang dalam sebuah tulisan melalui media spanduk dan buku panduan. Kebijakan yang telah dituliskan tersebut kemudian harus diimplementasikan dengan baik sehingga bisa menumbuhkan minat positif bagi para mahasiswa dan tentunya bisa menimbulkan hasrat yang baik untuk mahasiswa Fisip mengikuti aturan yang ada. Dari hasil penelitian juga ditemukan bahwa terdapat sebagian mahasiswa yang telah menjalankan dengan baik aturan tersebut. Hal ini tentunya merupakan suatu keputusan yang baik, yang telah diterapkan melalui tindakan atau kegiatan dari mahasiswa dan juga dosen di Fisip, Universitas Tadulako.

\section{Penutup}

\section{Kesimpulan}

Berdasarkan hasil penelitian dan pembahasan yang telah dianalisis secara sistematis dan didukung dengan temuan data di lapangan mengenai "Strategi Pimpinan Fakultas Ilmu Sosial dan Ilmu Politik Universitas Tadulako dalam 
Mengkomunikasikan Kebijakan kepada Mahasiswa", maka dapat ditarik kesimpulan bahwa pada dasarnya kebijakan itu sangat penting untuk diterapkan di Fakultas Ilmu Sosial dan Ilmu Politik Universitas Tadulako, karena dengan adanya kebijakan tentunya dapat dijadikan sebagai pedoman oleh para civitas akademika (mahasiswa) dalam melaksanakan proses perkuliahan menjadi lebih baik dan terarah sehingga dapat mengurangi dan bahkan menghilangkan perilaku yang tidak baik seperti melakukan pelanggaran aturan yang telah ditetapkan mengenai kebijakan yang terkait dengan presentasi kehadiran 75 $\%$ dan remedial.

1. Dalam menerapkan kebijakan yang ada, cara yang dilakukan oleh para pimpinan ialah dengan menggunakan komponen-komponen strategi komunikasi, diantaranya yaitu komunikator, pesan dan media :

a. Komunikator adalah pimpinan fakultas yang menyampaikan kebijakan kepada mahasiswa dapat dilihat dari dua faktor yaitu kepercayaan kepada komunikator dan daya tarik kepada komunikator. Kepercayaan kepada komunikator bahwa setiap pimpinan yang menyampaikan isi pesan tentang kebijakan akan dapat diterima langsung oleh mahasiswa dikarenakan jabatan yang dimilikinya sehingga mahasiswa percaya dengan pesan-pesan yang disampaikan yang berkaitan tentang presentasi kehadiran $75 \%$ dan remedial baik melalui komunikasi secara langsung ataupun melalui media spanduk dan buku pedoman. Sedangkan untuk daya tarik yaitu terletak pada karakteristik positif yang melekat pada diri pimpinan yaitu dengan menunjukkan sikap tegas, ramah dan adil serta bijaksana sehingga disenangi oleh para mahasiswa.

b. Pesan adalah informasi mengenai kebijakan atau aturan tentang presentasi kehadiran $75 \%$ dan remedial. Penyampaian isi pesan kepada mahasiswa yang dilakukan oleh pimpinan fakultas ialah dengan menggunakan pesan secara lisan baik disampaikan pada saat mengajar di dalam kelas ataupun di luar ruangan kelas, sedangkan untuk pesan secara tertulis yaitu menggunakan buku panduan dan spanduk.

c. Media adalah alat yang digunakan untuk menyampaikan pesan-pesan tentang kebijakan mengenai presentasi kehadiran $75 \%$ dan remedial. Media itu diantaranya berupa buku panduan fakultas dan spanduk yang ditempatkan di FISIP Park, Hot Spot dan di gedung Tata Usaha.

2. Faktor-faktor penghambat dalam penerapan strategi pimpinan Fakultas Ilmu Sosial Dan Ilmu Politik Universitas Tadulako dalam mengkomunikasikan kebijakan kepada mahasiswa yaitu kurangnya perhatian mahasiswa pada saat pimpinan memberikan pengarahan tentang kebijakan yang ada, adanya 
budaya malas membaca seperti membaca buku panduan, dan kerja sama yang buruk antara mahasiswa yang satu dengan mahasiswa yang lainnya dikarenakan faktor pertemanan yaitu dengan cara meniruh tanda tangan teman untuk dituliskan pada absen mata kuliah.

\section{Saran}

Dari hasil pemaparan dalam penelitian mengenai Strategi Pimpinan Fakultas Ilmu Sosial dan Ilmu Politik Universitas Tadulako dalam Mengkomunikasikan Kebijakan kepada Mahasiswa, maka saran yang diberikan oleh peneliti ialah sebagai berikut :

1. Dalam konteks komunikasi: sebagai pimpinan fakultas, kebijakan yang telah dibuat haruslah dikomunikasikan dengan lebih baik lagi, serta dapat mempertimbangkan berbagai macam unsur komunikasi yang digunakan diantaranya komunikator, pesan dan media itu sendiri. Tujuannya ialah untuk membantu mahasiswa agar dapat melaksanakan kebijakan atau aturan yang ada dengan maksimal.

2. Dalam konteks lembaga: bagi pimpinan fakultas, agar kiranya lebih mengefektifkan lagi kebijakan yang ada yaitu dengan cara memberikan sanksi yang lebih tegas bagi para mahasiswa dan dosen yang sering melanggar kebijakan yang telah dibuat demi mendapatkan hasil/tujuan yang maksimal.

\section{Daftar Pustaka}

Arifin, Anwar. 1994. Strategi Komunikasi. Bandung : Armico

Cangara, Hafied. 2004. Pengantar Ilmu Komunikasi. Raja Grafindo, Jakarta. . 2010. Pengantar Ilmu Komunikasi. Rajawali Pers : Jakarta.

Effendi, Onong Uchjana. 2003. Ilmu, Teori dan Filsafat Komunikasi. Bandung : Citra Aditya Bakti

Rosdakarya. Bandung 2009. Human Relations \& Public Relations. C.V Mandar Maju, Bandung.

Lampe, Ilyas. 2011. Komunikasi Organisasi : Teori dan Aplikasi. MARS PUBLISHERS, Palu.

Liliweri, Alo. 2011. Komunikasi Serba Ada Serba Makna. Kencana Prenada Media Group : Jakarta.

Muhammad, Arni. 2007. Komunikasi Organisasi. Bumi Aksara : Jakarta. 
Nurhaidar, 2009. Analisis Strategi Komunikasi Dinas Pariwisata Seni Dan Budaya Terhadap Peningkatan Kunjungan Wisatawan Pasca Konflik Di Kabupaten Poso. Universitas Hasanudin : Makassar. (Tidak dipublikasikan).

Nurhayani, 2011. Analisis Implementasi Kebijakan Program Nasional Pemberdayaan Masyarakat (PNPM) Mandiri Perkotaan dalam Meningkatkan Kesejahteraan Masyarakat di Kelurahan Siranindi Kecamatan Palu Barat, kota Palu. Universitas Tadulako : Palu. (Tidak Dipublikasikan).

Pace, R. Wayne dan Don F. Faules. 2005. Komunikasi Organisasi : Stratwahaegi Meningkatkan Kinerja Perusahaan. Remaja Rosdakarya : Bandung.

Purnamasari, Ika. 2011. Analisis Implementasi Kebijakan Program Nasional Pemberdayaan Masyarakat Mandiri Perkotaan di Kelurahan Donggala Kodi, Kecamatan Palu Barat, Kota Palu. Universitas Tadulako : Palu. (Tidak Dipublikasikan). 